\title{
KASZNÁR ATTILA
}

\section{A magyarországi kínai bevándorlás és annak nemzetiségi jogi aspektusai}

Sajnálatos módon, a Kínai Népköztársaságra még mindig sokan úgy tekintenek, mint egy furcsa egzotikumra, holott a távol-keleti állam mára már számtalan vonatkozásban bebizonyította, hogy korántsem az az ország, amely az elöítéletes nyugati gondolkodásban él.

A XXI. század második évtizedében egyértelmüvé vált, hogy a Kínai Népköztársaság, túlnőve korábbi regionális hatalmi pozícióján, a világpolitika egyik legbefolyásosabb, generális érdekérvényesítő képességű nagyhatalmává nőtte ki magát. Az ázsiai állam geostratégiai szerepéből adódóan gyakorlatilag lehetetlen olyan gazdasági, illetve államigazgatási szektort említeni, amelyben a lényegi döntések meghozatala előtt ne játszanának kitüntetett szerepet a Kínával, valamint a kínaiakkal összefüggő elemzések.

A közelmúltban meghirdetett keleti nyitás stratégiájának kiemelt célpontja a Kínai Népköztársaság. A magyar politikai vezetés szándéka volt, hogy a magyar-kínai kapcsolatokat a jövőben minden korábbinál magasabb szintre helyezve, jelentős gazdasági, valamint politikai előnyökhöz juttassa hazánkat. A kapcsolatok fejlesztése érdekében az utóbbi években kézzelfogható volt a magyar törekvés a magyar-kínai kapcsolatok élénkítésére. Ennek ellenére azonban - számos objektív, és talán még ennél is több szubjektív okra visszavezethetően - a két ország kapcsolata a folyamatos, jelentós élénkülés ellenére, még messze elmarad a lehetségestől.

A jobbításra irányuló szándék azonban egyértelmü, és a prognosztizálható gazdasági és politikai folyamatok elörevetítik azt is, hogy hazánkban mindinkább növekedni fog a kínai kapcsolatok szerepe.

Mind gyakrabban érkeznek Magyarországra kínai gazdasági, kulturális, illetve politikai delegációk, és élénkülés tapasztalható a magyar szakemberek Kínába látogatása kapcsán is. A Nyugaton tapasztalható „Kína-mánia”, ha lassan is, de Magyarországra is begyürüzött. Mind gyakrabban találkozhatunk kínai - leggyakrabban könnyen fogyasztható - témájú könyvekkel, amelyek egy-egy sajátos aspektusból ábrázolják a keleti országot. Egyremásra zajlanak itthon a Kínával kapcsolatos országos konferenciák, ezeknek 
szinte kizárólagos témája a magyar-kínai gazdasági kapcsolatok valamilyen „újszerü” megközelítése.

Amiről azonban egyáltalán nem vagy csak csekély szinten esik szó, az nem más, mint a Magyarországon élő kínai bevándorló közösség. Annak ellenére, hogy az elmúlt bő húsz évben a gyakorlatilag kisvárosnyi népességet kitevő ázsiai bevándorló a magyar lakosság mindennapjainak részévé vált, minimális az érdeklődés a magyarországi kínaiak iránt. Rendkívül csekély a Magyarországon élö kínaiakkal kapcsolatban rendelkezésre álló magyar nyelvü szakirodalom. „, A magyarországi kínai közösséggel kapcsolatos kutatások megközelitöleg húsz éves múltra tekinthetnek vissza. Ez alatt az idö alatt több-kevesebb sikerrel zajlottak az ázsiai országból érkezett migránsokkal összefüggö társadalomtudományi feldolgozómunkák. Elsősorban három kutató nevét kell megemliteni, akiknek ez irányú munkásságát nem lehet figyelmen kívül hagyni. Nyíri Pál, Mészáros Klára és Polonyi Péter a téma legavatottabb hazai szakértöinek számitanak. Azonban közülük a kérdéskörben folyamatos és aprólékos feldolgozómunkát csak Nyiri Pál végzett, Mészáros és Polonyi az évek folyamán szép lassan háttérbe szoritotta ez irányú tudományos tevékenységét. Amely érthetönek is tekinthetö, föképpen ha a hazai szakkutató intézetek, szakmai folyóiratok, valamint tudományos mühelyek - tegyük hozzá érthetetlen - téma iránti meglehetösen mérsékelt érdeklödését tekintjük." "I

Mint az idézetből is kitünik, a magyarországi kínai közösségekkel, illetve a kínai kultúrával, társadalomszerveződéssel kapcsolatos kutatások mind a mai napig meglehetősen szük spektrumban mozognak. Ezek elemzése alapján egyértelműen látszik, hogy Magyarországon továbbra sincs nincs meg a kellő érdeklődés aziránt, hogy az országban élő jelentős számú kínai bevándorlóval kapcsolatosan céltudatos kutatómunkák folyjanak. Holott egyre kevésbé tagadható, hogy szükséges volna a kérdéskörrel behatóan foglalkozni. Úgy tünik, mintha a magyar tudományos élet kicsit mostohagyermekként kezelné ezt a témát, amelynek fontossága azonban számos gazdaság- és biztonságpolitikai, menekült- és oktatásügyi, egészségügyi, rendvédelmi, valamint egyéb szakterületi kérdéseket vet fel. A kínai bevándorlás világméretü fontosságát szemlélteti, hogy egyes szakértői állásfoglalások szerint ,, a kínaiak mobilitása korunk egyik legjelentösebb migrációs jelensége a befogadó országok ma-

\footnotetext{
1 Kasznár Attila: Kínai közösség Magyarországon. In: Erdős Zoltán - Pálfy Eszter - Zárdai István Zoltán (szerk.): Törésvonalak. Pécsi Tudományegyetem Bölcsészettudományi Kar Kerényi Károly Szakkollégium-Lengyel Ifjúsági Egyesület, Pécs, 2011, 441. o.

http://www.unipo.sk/public/media/15062/69714652-Toresvonalak-konferenciakotet.pdf
} 
gas száma miatt, mivel 34 millió tengerentúli kínai (Chinese overseas), ahogyan a hazájukból elvándoroltakat nevezik, él a világ 130 országában”.".

Jelen tanulmány fö célja, hogy a Magyarországra irányuló kínai bevándorlás rövid történeti sajátosságainak, illetve ennek kulturális vonatkozásainak bemutatásán túlmenően, olyan elöre mutató, innovatív javaslatokat tegyen, amelyek nyomán egyrészt sikeresebb lehet a Magyarországon élő kínai nemzetiségü bevándorlók társadalmi integrációja, másrészt, ezzel összefüggésben sikeresebbé tehető a magyar-kínai gazdasági, kulturális és politikai kooperáció, amelynek révén hazánk jelentős nemzetgazdasági és egyben geostratégiai elönyökre tehet szert.

\section{A magyarországi kínai közösség kialakulása és sajátosságai}

A magyarországi kínai betelepülés gyakorlatilag párhuzamosan zajlott a rendszerváltozás eseményeivel. A szocialista államberendezkedés és a Szovjetunió összeomlása magával hozta a korábbi gazdasági szerkezetek ellehetetlenülését, az ipar és a piaci keretek válságát. Noha a hiánygazdaság megszünt, és megjelentek a Nyugatról származó, csábító, jó nevü fogyasztási cikkek, a növekvő munkanélküliség és az infláció következtében nagy részük a társadalom jelentös rétegének megfizethetetlen volt.

Az 1990-es évek elején Kelet-Közép-Európában kialakuló gazdasági recesszió nyomán megnőtt a munkanélküliség, azok pedig, akik nem vesztették el a munkahelyüket, azzal szembesültek, hogy a fizetésük emelkedése nem követi az árucikkek árának növekedését. Az életszínvonal gyors zuhanása, és a kiugró infláció hatásaként elszabadult árak következtében jelentősen csökkent a kereslet a márkásabb termékek iránt.

Az előbbiekből adódóan kialakult az igény a gyengébb minőségủ, így jóval olcsóbb termékek iránt, amelyekből viszont hiány keletkezett a piacon, hiszen a válság első körében éppen az olcsó áruk forgalmazásával foglalkozó kereskedelmi egységek mentek tönkre.

A hazánkban és a környező országokban zajló folyamatokkal nagyjából egy időben érte el a térséget az 1986-os kínai útlevél-liberalizáció hatására meginduló utazó kereskedők első hulláma. A Távol-Keletről érkező, vállal-

2 Irimiás Anna: Az új kínai migráció - a Budapesten élö kínai közösség. Statisztikai Szemle, 2009/78., 829. о. 
kozó szellemű bevándorlók gyorsan felismerték, hogy a hazájukban olcsón beszerzett, ennek következtében kedvező áron - mégis nagy haszonnal - továbbadható ruházati és egyéb textilipari termékek iránt kiugró kereslet mutatkozik a volt szovjet blokk államaiban. Az anyagi haszonszerzés új módjának tudatosulása vezetett oda, hogy mind nagyobb számban jelentek meg hazánkban azok a kínai nemzetiségü ingázók, akik gyakorlatilag hivatásszerűen kezdtek el foglalkozni a keresett termékek beszállításával. „Egy 1990ben Magyarországra érkezett kínai elmondása szerint akkoriban nem volt olyan áru, amit ne lehetett volna eladni. Nem voltak gazdasági megszoritások, és a könnyüipari termékek piaca is meghóditásra várt. "’ A lehetőségeket felismerve a Magyarországra beutazó kínaiak jelentős része azonban nemcsak rövid ideig akart hazánkban tartózkodni, hanem a jobb élet reményében, hosszabb-rövidebb idöre meg is akart itt telepedni, vagyis a tudományos terminológia alapján is bevándorlónak tekinthetők voltak. ${ }^{4}$ Mindazonáltal annak a tényét sem szabad figyelmen kívül hagyni, hogy a kínai állampolgárok kivándorlását erősen támogatta a pekingi kormányzat, amely gyakorlatilag a Matura Tamás által is kifejtett ${ }^{5}$ későbbi közép-európai gazdasági expanzió kezdőlépésének volt tekinthető.

A keleti blokk tagállamai közül a kínaiak Magyarország iránt mutatták a legnagyobb érdeklödést, ennek természetesen jelentős hajtóereje volt az, hogy „Magyarország volt az egyetlen európai ország, ahová vízum nélkül utazhattak a kinai állampolgárok. Ebben az idöszakban sok kinai érkezett Magyarországra Pekingböl, Északkelet-Kinából, Wenzhouból, Fujianból, Henanból és más kinai területekröl. "6 A Magyarország iránti kínai érdeklődést jól szemlélteti, hogy a hazánkba ,belépö kínai állampolgárok száma a nyolcvanas évek közepén regisztrált szinte zérusról 1990-ben 11 621-re, 1991-ben pedig 27 330-ra ugrott"'. Tényleges számuk azonban minden valószínüség szerint messze túlszárnyalta az idézett felmérés által mutatott számot, és a kutatók ,,általában negyvenezer felettire becsülik ennek az idöszaknak a kínai csúcslétszámát Magyarországon; az itt megfordultak száma még

3 http://hungarian.cri.cn/381/2011/04/21/2s134278.htm

4 Hautzinger Zoltán - Hegedüs Judit - Klenner Zoltán: A migráció elmélete. Nemzeti Közszolgálati Egyetem, Budapest, 2014, 88. o.

5 Matura, Tamás: China's Economic Expansion into Central Europe. In: Matura, Tamás (ed.): Asian Studies - 2013. Magyar Külügyi Intézet, Budapest, 2013, pp. 138-151.

$6 \mathrm{http} / /$ hungarian.cri.cn/381/2011/04/21/2s134278.htm

7 Nyíri Pál: Új ázsiai migráció Kelet-Európába: a magyarországi kínaiak. In: Kováts Nóra - Szarka László (szerk.): Tér és terep. Tanulmányok az etnicitás és az identitás kérdésköréböl III. Akadémiai Kiadó, Budapest, 2003, 163. o. 
magasabb lehetett"'. A Magyarországra érkező kínaiak jelentős része pedig rövid itt-tartózkodás után a nyugat-európai államok valamelyikébe távozott.

A vázolt folyamatok nyomán - az országot időközben elhagyók ellenére is - egy kisvárosnyi kínai bevándorló telepedett le Magyarországon. Lassan felnőnek az első generáció itt született gyermekei. Megállapítható, hogy az integrációjuk látszólag sikeresen zajlott, a közösség nem okoz jelentős társadalmi feszültséget. Mindamellett nem szabad figyelmen kívül hagyni annak a tényét, hogy a kínai az egyik leginkább a saját szokásaihoz, életmódjához ragaszkodó nemzet, ebböl adódóan a többségi társadalommal konfliktuskerülő ugyan, azonban korántsem tekintendő integrálódó közösségnek.

A magyarok és a kínaiak közötti konfrontációk ritkák, gyakorlatilag nem is beszélhetünk kínai bevándorlók ellen végrehajtott etnikai alapú támadásokról. Az ok egyszerú, és elsősorban a kulturális különbségben keresendö. Elmondható, hogy a két nép kultúrája, hagyományai és szokásai nagyon messze esnek egymástól, amelynek következtében a cselekedeteik során egymástól független közegben mozognak, gyakorlatilag egymásra kulturálisan minimálisan hatva élik mindennapjaikat. Ennek folytán kizárt ,, az új világ elfogadásához, az ottani többségi kultúra pozitiv elfogadásához, egyenrangúságának elismeréséhez elengedhetetlen tolerancia és együttmüködési szándék" hiánya.

A magyarok mindennapjaiba beszivárgó kínai kulturális dimenziónak tekinthető az ember és a természet harmóniáját hangsúlyozó fengsuj. Hasonlóan megemlíthető a kínai mozgáskultúra, vagyis az ázsiai harcmüvészetek némely irányzatainak terjedése. Továbbá idesorolható a mind nagyobb teret hódító, taoista alapú, tradicionális kínai orvoslás is.

A legjelentősebb a Kínai Népköztársaságot és a kínai kultúrát népszerüsítő, globális szervezetnek a Konfuciusz-Intézetek hálózata tekinthető, amelyekböl jelenleg négy müködik hazánkban, különböző felsőoktatási egységek mellé telepítve. ${ }^{10}$ Magyarországon számos további kínai-magyar gazdasági, kultúraközi, érdekvédelmi, illetve egyéb intézmény müködik.

Mint látható, a kínai közösség látszólag gond nélkül éli a mindennapjait Magyarországon, ugyanakkor nem szabad elfelejteni, hogy „, a kínai mig-

8 Polonyi Péter: A magyarországi kínai kolónia problémáiról. In: Inotai András - Juhász Ottó (szerk.): Kína: Realitás és esély. MTA Világgazdasági Kutatóintézet, Budapest, 2008, 328-346. o.

9 Bács Zoltán György: A radikalizáció és a terrorizmus kapcsolata, egyes formái, gondolatok a megelözés lehetséges perspektíváiról. Nemzetbiztonsági Szemle, 2017/1. 6. o.

10 Eötvös Loránd Tudományegyetem, Szegedi Tudományegyetem, Miskolci Egyetem és Pécsi Tudományegyetem. 
ránsközösségek túlnyomó részt a saját - bölcseleti filozófiai-vallási - szabályaik szerint élnek, amely többek között nagymértékben megneheziti a velük kapcsolatos idegenrendészeti, társadalombiztositási, rendvédelmi és adóhatósági fellépés sikerét" ${ }^{\prime \prime}$.

\section{A kínai közösséggel kapcsolatos nemzetiségi anomáliák}

Jelen tanulmánynak nem célja, hogy jogelméleti vitákban pró vagy kontra állást foglaljon, mindössze néhány alapvető jogszabályi jellegzetességre - esetleg hiányosságra - kívánja felhívni a figyelmet.

A nemzetiségek jogairól szóló 2011. évi CLXXIX. törvény 1. § (1) bekezdésében foglalt megfogalmazás szerint jelenleg Magyarországon ,,nemzetiség minden olyan - Magyarország területén legalább egy évszázada honos népcsoport, amely az állam lakossága körében számszerü kisebbségben van, a lakosság többi részétöl saját nyelve, kultúrája és hagyományai különböztetik meg, egyben olyan összetartozás-tudatról tesz bizonyságot, amely mindezek megőrzésére, történelmileg kialakult közösségeik érdekeinek kifejezésére

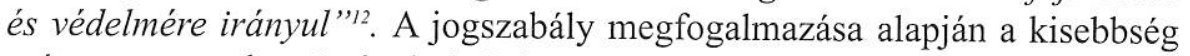
száma nem, csak a történelmi távlat, valamint a kulturális önazonosság határozza meg, hogy egy adott népcsoport nemzetiségnek minősül-e, vagy sem.

Ugyane törvény 1. melléklete alapján az iménti kritériumoknak jelenleg tizenhárom kisebbség felel meg Magyarországon, ,,nemzetiségnek minősül: a bolgár, a görög, a horvát, a lengyel, a német, az örmény, a roma, a román, a ruszin, a szerb, a szlovák, a szlovén és az ukrán'”'ls.

A nemzetiségi léthez természetesen hozzátartozik az is, hogy az adott népcsoportok „, a magyar politikai közösség részei, államalkotó tényezők"”l4, ezáltal pedig természetesen a nemzetiségek minden egyes tagja egyben Magyarország állampolgára is. A jelen tanulmány által érintett problémakör szempontjából kiemelt jelentőségünek tekinthetők a 3. szakaszban foglaltak, amelyek szerint: ,,minden nemzetiség jogosult arra, hogy nemzetiségi közösségként létezzen és fennmaradjon "'ls.

11 Kasznár Attila: Vallás és kormányzat Kínában. Bíbor Kiadó, Miskolc, 2016, 176. o.

$12 \mathrm{http} / / /$ net.jogtar.hu/jr/gen/hjegy_doc.cgi?docid=A1100179.TV

13 Uo.

14 Uo.

15 Uo. 
Megállapítható, hogy az idézett törvényi tényállások közül egy sem vonatkoztatható a Magyarországon tartózkodó kínai bevándorlókra. Vagyis, a nagyszámú, magyarországi kínai bevándorló közösségként kezelésének feltételei nem vagy csak részben megoldottak.

A probléma alapvető oka, hogy a magyarországi kínaiak túlnyomó többsége - egy kisszámú, szük réteget leszámítva - nem magyar állampolgár, ebből adódóan pedig nemzetiségi közösségként kezelésük is nehezen - a jogszabályi kereteket betartva, gyakorlatilag sehogy sem - kivitelezhetö, mind a jogalkotó, mind pedig a jogalkalmazó és a rendvédelmi szervezetek tekintetében. A Magyarországra érkezett kínaiak állampolgárság iránti csekély érdeklődését magyarázza, hogy a pekingi vezetés által „1980 szeptemberében jóváhagyott Állampolgársági Törvény azonban megszüntette a kettös állampolgárság intézményét. A külföldön korábban megtelepedett, kettös állampolgársági státusban lévőktöl automatikusan megvonták a kinai állampolgárságot"'16. A kínai bevándorlóknak pedig egyáltalán nem érdekük, hogy elveszítsék az állampolgárságukat. A ragaszkodás számos oldalról indokolható, ezek közül ki kell emelni a hagyományos - konfuciánus - kínai társadalom sajátosságait ${ }^{17}$, amelyek feltárása külön tanulmány/tanulmányok témája lehet. Egy a társadalmi-filozófiai magyarázatnál jóval könnyebben kezelhetö magyarázattal szolgál korábban idézett tanulmányában Kuo Hsziao Csing (Guo Xiaojing). Szerinte a kínai bevándorlók nem kívánnak magyar állampolgárságot szerezni, ennek ,oka azonban nem abban rejlik, hogy nem szeretnék Magyarországot, vagy hogy elutasitanák az európai életvitelt, értékeket [...] a kinai gazdasági fellendülés egy olyan speciális helyzetet teremt, hogy a józan ész azt diktálja: nem szabad kapukat bezárni, nem szabad felégetni az intézményes hidakat a világ legdinamikusabban fejlödö országa felé. A globalizáció fokozódása pedig megteremti a lokalitástól független társadalmi mobilitás lehetöségét. A kinai migránsok társadalmi mobilitási stratégiái a globális térben értelmezendök, és a lehetöségek állnak a középpontban. Márpedig a magyar állampolgárság kifejezetten korlátozó keretnek számit a földrajzi helytöl független lehetöségek terepén. "'s A magyarországi kínai bevándorlók magyar állampolgárság iránti passzivitása többé-kevésbé valószínüsíthetően a felsorolt tényezők komplex elegyéből adódhat.

16 Guo Xiaojing: Kínaiak és a magyar állampolgárság. In: Kováts András (szerk.): Magyarrá válni. MTA Kisebbségkutató Intézet, Budapest, 2011, 182-183. o.

17 A konfuciánus kínai társadalom alapja - ellentétben az európai társadalmi modell énközpontúságával - a család és az ősök tisztelete, ebből adódóan ha egy kínai elveszíti az állampolgárságát, akkor gyakorlatilag a kultúráját, a vallását és az őseit is elveszíti.

18 Guo Xiaojing: i. m. 188-189. o. 
A törvényi szabályozás tekintetében természetesen az sem változtatna jelentősen a tényeken, ha a magyarországi kínai bevándorlóközösség tagjai sorra folyamodnának magyar állampolgárságért, és tegyük föl, azt meg is kapnák. A jogszabályi kitételek alapján azonban még így sem volna lehetséges a nemzetiségként való kezelésük ${ }^{19}$, és nem élvezhetnék az ebből a szerzett státusból eredő előnyöket sem.

A tanulmány egyik vezérfonalaként jelezni kívánt jogszabályi anomália itt érhető tetten. Az 1989 óta Magyarországra érkező kínai bevándorlók jelentős része ilyen vagy olyan státusban, sokszor jogalap nélkül életvitelszerüen jelenleg is hazánkban tartózkodik. A Magyarországon élő kínaiak számával kapcsolatosan megbízható adat továbbra sem áll rendelkezésre. A korábban már jelzett, húszezret meghaladó szám mára kicsit túlzónak tünik. A másik végletet a 2011-ben végzett népszámlálási adatok adják, amelyek szerint 6770 kínai származású ember él hazánkban. ${ }^{20}$ Itt megjegyzendő, hogy a népszámlálási adatok, a népszámlálási, valamint a bevándorlóközösségre vonatkozó sajátosságok miatt, ebben a speciális esetben jelentős torzulásra adnak lehetőséget.

Irimiás Anna, a már idézett tanulmányában úgy fogalmaz, hogy , a Magyarországon élö kínai közösséget megfigyelve megállapithatjuk, hogy az ország népességének alacsony százalékát teszik ki a kinai bevándorlók. A hivatalos adatok szerint csak alig tizezer kínai él hazánkban, ugyanakkor feltételezhetjük, hogy számuk ezt jelentös mértékben meghaladja. "2l Mint látható, a legfrissebb hivatalos adatok jócskán el is maradnak a szerző által jelzettől, holott kimondva-kimondatlanul, de minden a szakterületen jártas személy tudja, hogy a magyarországi kínai bevándorlóközösség tényleges létszáma ezeket az adatokat messze túlszárnyalja. A tanulmány elkészítéséhez rendelkezésre álló kutatási lehetőségek mellett felelötlenség lenne a pontos szám meghatározására vállalkozni, mindamellett, ha a közösség jelenlegi létszámát húszezres becsült értékben adjuk meg, akkor nagy valószínűséggel a tényleges számhoz közelítő adatot kaphatunk.

Az előzőek alapján elmondható, hogy a XXI. század elején, Magyarországon húszezer ember él gyakorlatilag a közösségi jogok minimális szintü megléte nélkül.

19 „Legalább egy évszázada honos. ”

20 http://www.ksh.hu/nepszamlalas/tablak_demografia

21 Irimiás Anna: i. m. 829. o. 


\section{Összegzés és javaslatok}

A Magyarországon, az 1989 utáni időszakban megjelenő kínai bevándorlóközösség számos államigazgatási, jogszabályi, szociálpolitikai anomáliát, valamint számtalan lehetőséget hozott a felszínre. Íme, néhány, a kínai közösséggel összefüggő és megoldásra váró probléma, valamint a rájuk adandó lehetséges - a remények szerint célravezető - válasz, valamint a bevándorlókkal összefüggő nemzetgazdasági és társadalmi szinten megjelenő előnyök közül.

Az elözőkben leírtak alapján kijelenthetö, hogy a kínai bevándorló tömeg megjelenése és nagyszámú letelepedése rávilágított arra a jogszabályi hézagra, hogy a nemzetiségnek nem minősülő, azonban a nemzetiség számos jegyét magán hordozó bevándorló csoport magyarországi megjelenésével, és a nemzeti közösségbe történő beillesztésével a magyar törvényi szabályozás a jelenlegi keretek között nem tud mit kezdeni.

A kérdéskör azonban rendkívüli jelentőséggel bírhat (táblázat), hiszen ha elfogadjuk, hogy megközelítőleg húszezerre tehető a kínai nemzetiségüek száma hazánkban, akkor a hatodik legnagyobb magyarországi kisebbségnek tekinthetö.

A probléma komplex, hiszen számos kínai bevándorló évtizedek óta, életvitelszerüen él Magyarországon, de nincs magyar állampolgárságuk, és a legtöbbjük nem is szándékozik ilyet szerezni. Az a tény azonban, hogy egy húsz-

A magyarországi kisebbségek lélekszámára vonatkozó adatok

\begin{tabular}{|l|r|}
\hline bolgár & 6272 \\
cigány (romani, beás) & 315583 \\
görög & 4642 \\
horvát & 26774 \\
lengyel & 7001 \\
német & 185696 \\
örmény & 3571 \\
román & 35641 \\
ruszin & 3882 \\
szerb & 10038 \\
szlovák & 35208 \\
szlovén & 2820 \\
ukrán & 7396 \\
hazai nemzetiségek & \\
együtt & 644524 \\
\hline
\end{tabular}

Forrás: http://www.ksh.hu/nepszamlalas/tablak_demografia 2017. július 1 . 
ezerre tehető homogén kulturális egységet alkotó közösség egységes képviselete nem megoldott, jelentös aggodalomra adhat okot.

Kiemelt szakintézményi feladat lehet a közeljövöben egy olyan jogszabálytervezet előkészítése, amely rendezné a kínai bevándorlók közösségi jogait. A jogszabály ezzel egyben elé menne a XXI. századi, új típusú biztonsági kockázatok jelentette feladatoknak is.

Amint az a 1035/2012. (II. 21.) kormányhatározat keretében elfogadott Magyarország Nemzeti Biztonsági Stratégiájában is szerepel: „,A migrációt természetes, ugyanakkor összetett jelenségként kezeljük, amely gazdasági és demográfiai elönyöket, valamint köz- és nemzetbiztonsági kockázatokat egyaránt magában rejt. Magyarország határainak egy része a belátható jövőben is az EU vagy a schengeni térség külsö határa marad, ami együtt jár az uniós határszakasz igazgatásának felelösségével és feladataival. Az illegális migráció Magyarországot jelenleg elsösorban tranzitországként érinti, azonban hosszabb távon nem zárható ki, hogy az illegális migrációban érintettek nagyobb része célországként tekintsen hazánkra. Az illegális migráció megjelenésével együtt járó biztonsági kockázatok kezelése az uniós tagságból fakadó kötelezettségek teljesitése mellett nemzeti érdek is, ezért az ebböl fakadó biztonsági kérdéseket nemzetközi együttmüködés keretében kezeljük. "’22

A jogszabály alapján a menekültkérdés, és elsősorban az illegális bevándorlás jelentette biztonsági teendők kiemelt nemzeti feladatnak számítanak. A XXI. század első évtizedében világosan megmutatkozott, hogy a menekültkérdés és a hozzá kapcsolódó, rendkívül széles problémakör az egyik legjelentősebb, világméretü gazdasági, kulturális, valamint biztonsági kockázatokat jelentő konfliktusforrássá vált.

A magyarországi kínai közösség képviseletét rendező jogszabály megteremthetné annak a lehetőségét is, hogy ha valamilyen regionális konfliktus hatására hazánk nagyobb számú, azonos etnikumú bevándorlók célországává válna, akkor az ebből adódó problémákra már előzetesen felkészülten tekinthessünk.

Célszerủ a kormányzati lehetőségek keretében hatni a magyarországi kínai közösség képviseletének alakulására is. Korábban gyakori gond volt, hogy egyes önjelölt személyek a kínai közösség nevében intézményi kapcsolattartásra törekedtek. Az ilyen tárgyalások keretében kötött megállapodások azonban Magyarország számára nem hoztak hasznot, sőt számos esetben

22 Magyarország Nemzeti Biztonság Stratégiája.

http://www.kormany.hu/download/f/49/70000/1035_2012_korm_hatarozat.pdf 
nemcsak a bevándorlóközösséggel összefüggő kapcsolattartást nehezítette meg, de a magyar-kínai államközi viszonyra is rányomta a bélyegét.

A magyarországi kínai bevándorlókkal tartott állami kapcsolatoknak a kínaiak részéről történő intézményesítésének elősegítése a kiemelt nemzeti projektek között kell, hogy szerepet kapjon. A megfelelö keretek közötti párbeszéd jelentős nemzetgazdasági hasznot hozhat, valamint hozzájárulhat a két ország kapcsolatának további erősödéséhez is.

A kormányzat keleti nyitás stratégiájával összhangban kiemelt szerepet kell kapnia az államigazgatási struktúrában a kínai nyelvi képzésnek. ${ }^{23} \mathrm{~A}$ kínai bevándorlókkal történő kapcsolattartást rendkívüli módon előmozdítaná a nyelvi nehézségek ilyen szintü kiküszöbölése. A jelenleg kiemelt állami munkavállalói célrétegnek tekinthető $\mathrm{Y}$ generáció ${ }^{24}$ - a nemzetbiztonsági szolgálatok esetében például ,a felvételi eljárásra jelentkezök döntö többsége a 20-35 éves korosztályból kerül ki "25 - különösképpen alkalmas lehet a képzésekre, hiszen már az élete része a folyamatos tanulás.

A szakfeladatokat ellátó intézmények munkatársainak kínai nyelvi képzése azzal az elönnyel is járhat, hogy megtakarítható vele a tolmácsoknak fizetett díjazás.

Az idegenrendészeti meghallgatások során számos félreértés kiszürhetővé válna, ha a meghallgató közvetlenül tudna kommunikálni a meghallgatottal, vagy legalább képes volna bizonyos szintü kommunikációra. Az a tény sem elhanyagolható, hogy minden bizonnyal a bevándorlók is nyitottabbá válnának attól, hogy valaki beszéli a nyelvüket.

A megismerés az elfogadáshoz vezető legfontosabb lépcsők egyike. Sajnálatos módon a magyar társadalom rendkívül kirekesztő, ebből adódóan, jókora elöítélettel viszonyul a külföldiekhez. A kínai kisebbséggel összefüggésben meglévő sztereotípiák az elmúlt két évtizedben nem vagy csak részben mérséklődtek. Az elöítéletesség sajnálatos módon az állami szférában is jelen van, csökkentése összehangolt kormányzati feladatokat igényel.

A kínai kultúra ma már számos forrásból megismerhető Magyarországon. A magyarországi kínai kultúrával összefüggésben létrehozott, korábban felsorolt intézmények - elsősorban a Konfuciusz-intézetek - remek alkalmat kí-

23 Jelen tanulmánynak nem közvetlen témája ugyan, azonban fontos kiemelni, hogy számos egyéb, ma még a magyar köztudatban egzotikusnak tartott nyelv oktatása válhat fontossá a közigazgatási intézmények keretében.

24 Az 1980 és 1995 között születettek.

25 Zalai Noémi: Új típusú kihívások: generációváltás a nemzetbiztonsági szolgálatoknál. Nemzetbiztonsági Szemle, 2016/1., 38-39. o. 
nálnak arra, hogy megismerkedhessünk a távol-keleti ország jellegzetességeivel. Megfontolásra érdemes, hogy az adott szakigazgatási feladatokat ellátó intézmények - amelyek munkatársai kapcsolatba kerülnek kínaiakkal képzési szerződéseket kössenek a Konfuciusz-intézetekkel, ezáltal elősegítve, hogy a munkatársak jobb kapcsolatot építhessenek ki a távol-keleti bevándorlókkal.

A magyarországi kínai bevándorlók kapcsán természetesen számos területen adódnak és adódhatnak olyan elemek, amelyek javitásra szorulhatnak, illetve amelyek korrigálása jelentős nemzeti előnyökhöz juttathatja Magyarországot.

\section{IRODALOM}

Bács Zoltán György: A radikalizáció és a terrorizmus kapcsolata, egyes formái, gondolatok a megelözés lehetséges perspektíváiról. Nemzetbiztonsági Szemle, 2017/1. 5-26. o.

Hautzinger Zoltán - Hegedüs Judit - Klenner Zoltán: A migráció elmélete. Nemzeti Közszolgálati Egyetem, Budapest, 2014

Irimiás Anna: Az új kínai migráció - a Budapesten élő kínai közösség. Statisztikai Szemle, 2009/7-8.

Kasznár Attila: Kínai közösség Magyarországon. In: Erdős Zoltán - Pálfy Eszter - Zárdai István Zoltán (szerk.): Törésvonalak. Pécsi Tudománegyetem Bölcsészettudományi Kar Kerényi Károly Szakkollégium-Lengyel Ifjúsági Egyesület, Pécs, 2011

http://www.unipo.sk/public/media/15062/69714652-Toresvonalak-konferenciakotet.pdf

Kasznár Attila: Vallás és kormányzat Kínában. Bíbor Kiadó, Miskolc, 2016

Matura, Tamás: China's Economic Expansion into Central Europe. In: Matura, Tamás (ed.): Asian Studies - 2013. Magyar Külügyi Intézet, Budapest, 2013, pp. 138-151.

Nyíri Pál: Új ázsiai migráció Kelet-Európába: a magyarországi kínaiak. In: Kováts Nóra Szarka László (szerk.): Tér és terep. Tanulmányok az etnicitás és az identitás kérdésköréből III. Akadémiai Kiadó, Budapest, 2003, 163. o.

Polonyi Péter: A magyarországi kínai kolónia problémáiról. In: Inotai András - Juhász Ottó (szerk.): Kína: Realitás és esély. MTA Világgazdasági Kutatóintézet, Budapest, 2008, 328346. 0 .

Xiaojing, Guo: Kínaiak és a magyar állampolgárság. In: Kováts András (szerk.): Magyarrá válni. MTA Kisebbségkutató Intézet, Budapest, 2011, 182-183. o.

Zalai Noémi: Új típusú kihívások: generációváltás a nemzetbiztonsági szolgálatoknál. Nemzetbiztonsági Szemle, 2016/1. 